\title{
Perilaku Merokok dan Faktor yang Berhubungan pada Siswa
}

\section{Smoking Behavior and Factors Related to Students}

\author{
Yuhelva Destri $^{1 凶}$, Fitri Eka Sari², Agung Aji Perdana ${ }^{2}$ \\ ${ }^{1}$ STIKES Adila di Kota Bandar Lampung \\ ${ }^{2}$ Program Pasca Sarjana Fakultas Kesehatan Masyarakat Universitas Malahayati \\ ${ }^{凶}$ Corresponding author: yuhelvadestri85@gmail.com
}

\author{
Kata kunci: \\ Perilaku merokok \\ siswa; \\ Teman sebaya; \\ Pengaruh guru; \\ Pengaruh keluarga.
}

Keyword:

Student smoking;

behavior;

Student peers;

Teacher influence;

Family influence.

\begin{abstract}
Abstrak
Latar belakang: Indonesia menduduki ranking satu dengan jumlah perokok tertinggi di dunia dan Asia Tenggara. Perilaku merokok di Indonesia semakin muda usia,semakin besar yang merokok. Tujuan: Tujuan penelitian ini untuk menganalisis faktor dominan perilaku merokok pada siswa. Metode: Jenis penelitian ini adalah penelitian kuantitatif dengan rancangan cross sectional. Populasi penelitian adalah seluruh siswa SMK X Jati Agung Lampung Selatan tahun 2018 yang berjenis kelamin laki-laki dengan sampel berjumlah 169 siswa. Pengumpulan data menggunakan alat kuesioner. Analisis data menggunakan analisis univariat dan analisis bivariat. Hasil: Hasil penelitian menunjukkan responden dengan perilaku merokok 55,6\%. Hasil analisis memperoleh ada hubungan secara statistik antara terpengaruh teman sebaya, keterpaparan iklan rokok, lingkungan keluarga, pengaruh guru, uang jajan dengan perilaku merokok responden. Sedangkan yang tidak berhubungan adalah faktor pengetahuan dan pola asuh. Simpulan: Terpengaruh teman sebaya, keterpaparan iklan rokok, lingkungan keluarga, terpengaruh guru dan uang jajan meningkatkan kejadian perilaku merokok. Perlu upaya mencegah perilaku merokok dengan memberikan keteladanan kepada siswa dari teman sebaya keluarga, guru maupun pengaturan iklan rokok oleh pemerintah.
\end{abstract}

\begin{abstract}
Background: Indonesia ranks first with the highest number of smokers in the world and Southeast Asia. Smoking behavior in Indonesia is getting younger, the greater the smoking. Purpose: The purpose of this study is to analyze the dominant factors of smoking behavior in students. Methods: This research type is quantitative research with cross sectional design. The study population was all students of SMK X Jati Agung South Lampung in 2018 who were male with a sample of 169 students. Data collection using a questionnaire tool. Data analysis using univariate analysis and bivariate analysis. Results: The results showed respondents with smoking behavior 55.6\%. The results of the analysis found there was a statistical relationship between peers affected, exposure to cigarette advertisements, family environment, teacher influence, allowance with smoking behavior of respondents. While the unrelated factors are knowledge and parenting. Conclusion: Influenced by peers, exposure to cigarette advertisements, family environment, influenced by teachers and allowance to increase the incidence of smoking behavior. Efforts should be made to prevent smoking by giving role models to students from family peers, teachers and regulating cigarette advertisements by the government.
\end{abstract}

Copyright $(2019$ Jurnal Kesehatan Metro Sai Wawai. All rights reserved. 


\section{Latar Belakang}

Indonesia menduduki ranking satu dengan jumlah perokok tertinggi di dunia. Jumlah perokok di Indonesia tahun 2016 mencapai 90 juta jiwa. Indonesia sendiri menempati urutan tertinggi prevalensi merokok bagi laki-laki di ASEAN yakni sebesar 67,4\%. Kenyataan ini diperparah bahwa perokok di Indonesia usianya semakin muda. Data Komisi Nasional Perlindungan Anak menunjukkan jumlah perokok anak di bawah 10 tahun di Indonesia mencapai 239.000 orang, 19,8\% pertama kali mencoba rokok sebelum usia 10 tahun, dan hampir $88,6 \%$ pertama kali mencobanya di bawah 13 tahun. Prevalensi merokok di Indonesia sangat tinggi di berbagai lapisan masyarakat, terutama pada laki-laki mulai dari anak-anak, remaja dan dewasa. Kecenderungan merokok terus meningkat dari tahun ke tahun pada lakilaki dan perempuan. Hampir 80\% perokok mulai merokok ketika usianya belum mencapai 19 tahun. Umumnya orang mulai merokok sejak muda dan tidak tahu risiko mengenai bahaya adiktif rokok. Keputusan konsumen untuk membeli rokok tidak didasarkan pada informasi yang cukup tentang risiko produk yang dibeli, efek ketagaihan dan dampak pembelian yang dibebankan pada orang lain (Kemenkes RI, 2016).

Provinsi Lampung menduduki peringkat keenam dari 33 provinsi di Indonesia dengan jumlah perokok 26,5\% dari rata-rata jumlah perokok di Indonesia sebesar 29,3\% (Trihono, 2013). Jumlah penduduk umur 10 tahun ke atas menurut kebiasaan merokok di Kabupaten Lampung Selatan 27,2\%. Prevalensi perokok saat ini penduduk umur 10 tahun keatas sebesar 34,9\% yang merupakan urutan ketiga setelah Kabupaten Lampung Barat dan Tanggamus, rata-rata jumlah batang rokok yang dihisap 10,26 batang. Jumlah penduduk umur 10 tahun ke atas yang merokok menurut usia mulai merokok tiap hari, terbanyak pada usia 15-19 tahun sebesar 44,9\%, lebih tinggi dari usia merokok 15-19 tahun menurut provinsi Lampung yang hanya 36,3\% (Badan Penelitian dan Pengembangan Kesehatan Departemen Kesehatan RI, 2009).

Berbagai faktor yang melatarbelakangi perilaku merokok pada remaja antara lain faktor intrinsik yang meliputi faktor jenis kelamin, faktor kepribadian, faktor pekerjaan dan faktor kepercayaan. Sedangkan, faktor ekstrinsik meliputi pengaruh keluarga dan lingkungaan sekitar, pengaruh teman sebaya pengaruh iklim, iklan rokok, kemudahan memperoleh rokok, tidak adanya aturan serta sikap petugas kesehatan (Farida, 2015).

Hasil studi pendahuluan melalui wawancara dengan guru Bimbingan Konseling (BK) pada 4 Sekolah Menengah Atas (SMA) atau sederajat di Kecamatan Jati Agung Lampung Selatan, menunjukkan bahwa lebih dari 50\% siswa laki-laki adalah perokok. Jumlah terbanyak siswa merokok ditemukan di Sekolah Menengah Kejuruan (SMK) Al-Huda Jati Agung. Guru BK tersebut menambahkan, beberapa siswa yang merokok cenderung mengalami penurunan dalam hasil belajar dan terkadang juga membolos sekolah dan sanksi yang diberikan pada siswa yang merokok dari teguran secara lisan sampai pemanggilan orang tua. Berdasarkan pemanggilan beberapa orang tua yang berkaitan dengan siswa merokok, orang tua mengetahui jika anaknya merokok. Salah satu siswa mengutarakan bahwa ia merokok sejak Sekolah Menengah Pertama (SMP), karena ikut dengan pergaulan teman-teman sebaya. Ia terkadang merokok saat berada di belakang sekolah atau pada jam mata pelajaran yang kosong, bahkan terkadang juga ia merokok saat berada di kantin. Hasil wawancara dengan empat siswa perempuan, mereka membenarkan jika banyak siswa laki-laki yang merokok dan tidak ada siswa perempuan yang merokok. Wawancara dengan pemilik warung yang berada di sekitar sekolah membenarkan bahwa disaat waktu istirahat dan pulang sekolah banyak siswa yang membeli rokok dan menghisapnya.

Merokok berakibat buruk, apalagi pada usia muda. Remaja dapat kehilangan produktivitas dan kecacatan. Produktivitas tenaga kerja Indonesia hanya sekitar 21,9 dolar AS berada di bawah Malaysia, dan Thailand bahkan Sri Lanka. Sedangkan, kecacatan di Indonesia menurut data Global Adult Tobacco Survei, kecacatan akibat tembakau adalah lebih dari 3,5 juta tahun hidup hal ini setara dengan 
kehilangan ekonomi sebesar 106 triliun rupiah. Selain itu, merokok menjadi faktor risiko mematikan, merokok merenggut nyawa setidaknya 244.000 orang setiap tahunnya (Sinaga, 2017).

Adanya komitmen yang kuat, jejaring yang erat, dan tindakan pasti Pemerintah Pusat dan Daerah bersama seluruh masyarakat adalah modal dasar dalam mewujudkan Indonesia Bebas Asap Rokok. Kawasan Tanpa Rokok (KTR) di tingkat Kabupaten/ Kota hendaknya semakin diperluas cakupan dan jangkauannya di Indonesia melalui penerbitan regulasi dan implementasi. Dewasa ini, sudah ada 220 Kabupaten/Kota di 34 Provinsi yang memiliki peraturan terkait Kawasan Tanpa Rokok (KTR). Langkah ini penting demi melindungi masyarakat dari ancaman gangguan kesehatan akibat lingkungan yang tercemar asap rokok. Guna meningkatkan kemauan dan kemampuan masyarakat untuk hidup sehat dengan upaya advokasi, sosialisasi, dan penerbitan regulasi, perlu diperkuat dengan pelembagaan Perilaku Hidup Bersih dan Sehat (PHBS) serta perilaku CERDIK, yang merupakan kepanjangan dari Cek Kesehatan Secara Berkala; Enyahkan Asap Rokok; Rajin Beraktifitas Fisik; Diet Sehat dan Seimbang; Istirahat Cukup; dan Kelola Stress (Kemenkes RI, 2016) Hasil studi pendahuluan melalui wawancara dengan guru Bimbingan Konseling (BK) pada 4 Sekolah Menengah Atas (SMA) atau sederajat di Kecamatan Jati Agung Lampung Selatan, menunjukkan bahwa lebih dari 50\% siswa laki-laki adalah perokok. Jumlah terbanyak siswa merokok ditemukan di Sekolah Menengah Kejuruan (SMK) X Jati Agung. Guru BK tersebut menambahkan, beberapa siswa yang merokok cenderung mengalami penurunan dalam hasil belajar dan terkadang juga membolos sekolah dan sanksi yang diberikan pada siswa yang merokok dari teguran secara lisan sampai pemanggilan orang tua. Berbagai penelitian tentang perilaku merokok telah dilakukan,. Namun, penelitin ini menganalisis di salah satu sekolah di Lampung Selatan yang masih jarang dilakukan penelitian tentang perilaku merokok yang melibatkan berbagai variabel faktor risiko. Penelitian ini bertujuan mengkaji determinan perilaku merokok pada siswa siswa SMK X Jati Agung Lampung Selatan Tahun 2018.

\section{Metode}

Jenis penelitian ini adalah penelitian kuantitatif dengan rancangan cross sectional. Rancangan ini digunakan untuk membuktikan faktor-faktor yang berhubungan dengan perilaku merokok pada siswa. Penelitian dilakukan pada bulan Oktober 2017 sampai Desember 2018. Populasi dalam penelitian ini adalah seluruh siswa SMK X Jati Agung Lampung Selatan yang berjenis kelamin laki-laki sebanyak 344 siswa. Sampel berjumlah 169 siswa dari kelas X-XI yang diambil menggunakan teknik proportional stratified random sampling. Jenis data yang digunakan pada penelitian ini adalah data primer.

Pengumpulan data dengan menyebarkan angket dan wawancara. Instrumen yang digunakan adalah kuesioner yang berisi pertanyaan-pertanyaan setiap variabel penelitian. Hasil pengukuran memperoleh data kategorik. Variabel dependen adalah perilaku merokok hasil pengukuran dikategorikan merokok atau tidak merokok, tingkat pengetahuan dengan hasil pengetahuan rendah atau baik, pola asuh orang tua dengan hasil otoriter atau demokratis, teman sebaya dengan hasil berpengaruh atau tidak terpengaruh, keterpaparan iklan rokok dengan hasil terpengaruh atau tidak, lingkungan keluarga merokok atau tidak merokok, guru merokok atau tidak dan uang jajan tinggi atau rendah. Pengumpulan data didukung dengan wawancara untuk memperoleh data kualitatif secara mendalam berbagai faktor determinan perilaku merokok pada siswa.

Hasill penelitian dianalisis secara bertahap mulai analisis univariat dengan distribusi frekuensi dan analisis bivariat dengan uji chi square. Pertimbangan kaji etik (ethical clearance) penelitian diperoleh dari Komisi Etik Politeknik Kesehatan Tanjung Karangdan penelitian dilakukan setelah mendapat izin penelitian dari SMK Jati Agung Lampung Selatan, kemudian informed consent dari responden. 


\section{Hasil}

\section{Gambaran responden}

Penelitian melibatkan responden seluruh siswa laki-laki berjumlah 169 orang. Responden adalah siswa kelas X - XI. Hasil analisis memperoleh siswa laki-laki yang berperilaku merokok terdapat $55,6 \%$, tingkat pengetahuan rendah $23,2 \%$, pola asuh orang tua yang demokratis 88,2 , pengaruh teman sebaya $53,3 \%$, terpengaruh paparan iklan rokok $78,1 \%$, lingkungan keluarga merokok $87,0 \%$, dan uang jajan tinggi 35,5\% (lihat tabel 1).

Tabel 1.

Distribusi responden menurut masing-masing variabel pada Siswa SMK X Jati Agung Lampung Selatan Tahun 2018

\begin{tabular}{|c|c|c|c|}
\hline $\begin{array}{r}\text { Variabel } \\
\end{array}$ & Kategori & Jumlah $(n=169)$ & $\%$ \\
\hline \multirow[t]{2}{*}{ Perilaku merokok } & $\mathrm{Ya}$ & 94 & 55,6 \\
\hline & Tidak & 75 & 44,4 \\
\hline \multirow[t]{2}{*}{ Pengetahuan } & Kurang & 39 & 23,1 \\
\hline & Baik & 130 & 76,9 \\
\hline \multirow[t]{2}{*}{ Pola asuh } & Otoriter & 20 & 11,8 \\
\hline & Demokratis & 149 & 88,2 \\
\hline \multirow[t]{2}{*}{ Terpengaruh teman sebaya } & Ada & 90 & 53,3 \\
\hline & Tidak ada & 79 & 46,7 \\
\hline \multirow[t]{2}{*}{ Keterpaparan iklan rokok } & Terpengaruh & 132 & 78,1 \\
\hline & Tidak terpengaruh & 37 & 21,9 \\
\hline \multirow[t]{2}{*}{ Lingkungan keluarga merokok } & Ada & 22 & 13,0 \\
\hline & Tidak ada & 147 & 87,0 \\
\hline \multirow[t]{2}{*}{ Terpengaruh guru merokok } & Ada & 100 & 59,2 \\
\hline & Tidak ada & 69 & 40,8 \\
\hline \multirow[t]{2}{*}{ Uang jajan } & Rendah & 109 & 64,5 \\
\hline & Tinggi & 60 & 35,5 \\
\hline
\end{tabular}

\section{Hasil analisis bivariat}

Tabel 2 menunjukkan bahwa secara statistik terdapat lima variabel yang memiliki hubungan dengan perilaku merokok siswa SMK X Jati Agung Lampung Selatan tahun 2018 karena p value < 0,05 yaitu pengaruh teman sebaya $(\mathrm{p}=0,000 ; \mathrm{OR}=73,299$ CI 95\%: 0,304-1,970), keterpaparan iklan rokok $(\mathrm{p}=0,002 ; \mathrm{OR}=3,417$ CI 95\%: 1,577-7,401), lingkungan keluarga $(\mathrm{p}=0,001 ; \mathrm{OR}=9,865$ CI 95\%: 2,22543,731), pengaruh guru $(\mathrm{p}=0,000 ; \mathrm{OR}=4,375$ CI 95\%: $2,274-8,418)$ dan uang jajan $(\mathrm{p}=0,009$; $\mathrm{OR}=0,391)$. Sedangkan, dua variabel yang tidak berhubungan karena $\mathrm{p}$ value $>0,05$ yaitu pengetahuan dan pola asuh.

\section{Pembahasan}

\section{Perilaku merokok}

Perilaku merupakan semua kegiatan atau aktivitas manusia, baik yang dapat diamati langsung, maupun yang tidak dapat diamati oleh pihak luar (Novita \& Yunetra Franciska, 2011). Seseorang berperilaku tertentu berdasarkan pengetahuan, orang penting sebagai referensi untuk dicontoh, sumber daya mencakup fasilitas, dan uang (WHO, 1984 dalam Syafrudin \& Yudhia Fratidhina, 2009).

Hasil penelitian menunjukkan bahwa responden lebih banyak yang merokok $(55,6 \%)$. Faktor yang mendorong remaja untuk merokok amat beragam, antara lain bentuk jati diri, orang tua yang perokok, guru yang merokok dan pengaruh teman sebaya. Selain itu, faktor lingkungan yang mempengaruhi seseorang untuk mulai merokok adalah iklan dan faktor kemudahan mendapatkan rokok, baik dari sudut harganya yang relatif murah maupun ketersediaanya di mana-mana. 
Tabel 2.

Hubungan faktor-faktor yang berhubungan dengan perilaku merokok siswa

\begin{tabular}{|c|c|c|c|c|c|c|c|}
\hline \multirow{3}{*}{ Variabel } & \multicolumn{4}{|c|}{ Perilaku Merokok } & \multirow{3}{*}{ Jumlah } & \multirow{3}{*}{$\begin{array}{c}P \\
\text { value }\end{array}$} & \multirow{3}{*}{$\begin{array}{c}\text { OR } \\
\text { CI } 95 \%\end{array}$} \\
\hline & \multirow{2}{*}{$\begin{array}{c}\mathbf{Y a} \\
\mathrm{n}=94\end{array}$} & \multicolumn{3}{|c|}{ Tidak } & & & \\
\hline & & $\%$ & $n=74$ & $\%$ & & & \\
\hline \multicolumn{8}{|l|}{ Pengetahuan } \\
\hline Kurang & 26 & 66,7 & 13 & 33,3 & 39 & \multirow[t]{2}{*}{0,162} & 1,824 \\
\hline Baik & 68 & 52,3 & 62 & 47,7 & 130 & & $(0,862-3,858)$ \\
\hline \multicolumn{8}{|l|}{ Pola asuh } \\
\hline Otoriter & 10 & 50,0 & 10 & 50,0 & 20 & \multirow[t]{2}{*}{0,765} & 0,774 \\
\hline Demokratis & 84 & 56,4 & 65 & 43,6 & 149 & & $(0,304-1,970)$ \\
\hline \multicolumn{8}{|c|}{ Terpengaruh teman sebaya } \\
\hline Ada & 83 & 92,2 & 7 & 7,8 & 90 & \multirow[t]{2}{*}{0,000} & 73,299 \\
\hline Tidak ada & 11 & 13,9 & 68 & 86,1 & 79 & & $(26,955-99,324)$ \\
\hline \multicolumn{8}{|c|}{ Keterpaparan iklan rokok } \\
\hline Terpengaruh & 82 & 62,1 & 50 & 37,9 & 132 & \multirow[t]{2}{*}{0,002} & 3,417 \\
\hline Tidak terpengaruh & 12 & 32,4 & 25 & 67,6 & 37 & & $(1,577-7,401)$ \\
\hline \multicolumn{8}{|c|}{ Lingkungan keluarga merokok } \\
\hline Ada & 20 & 90,9 & 2 & 9,1 & 22 & \multirow[t]{2}{*}{0,001} & 9,865 \\
\hline Tidak ada & 74 & 50,3 & 73 & 49,7 & 147 & & $(2,225-43,731)$ \\
\hline \multicolumn{8}{|c|}{ Terpengaruh guru merokok } \\
\hline Ada & 70 & 70,0 & 30 & 30,0 & 100 & \multirow[t]{2}{*}{0,000} & 4,375 \\
\hline Tidak ada & 24 & 34,8 & 45 & 65,2 & 69 & & $(2,274-8,418)$ \\
\hline \multicolumn{8}{|l|}{ Uang jajan } \\
\hline Rendah & 52 & 47,7 & 57 & 52,3 & 109 & \multirow[t]{2}{*}{0,009} & 0,391 \\
\hline Tinggi & 42 & 70,0 & 18 & 30,0 & 60 & & $(0,762)$ \\
\hline
\end{tabular}

Banyak faktor-faktor yang melatarbelakangi perilaku merokok remaja. Secara umum, perilaku merokok merupakan fungsi dari lingkungan dan individu. Artinya, perilaku merokok selain disebabkan faktorfaktor dari dalam diri juga disebabkan faktor lingkungan. Faktor dalam remaja dapat dilihat dari kajian perkembangan remaja yang mulai merokok berhubungan dengan krisis aspek psikososial yang dialami pada masa perkembangan, ketika mereka sedang mencari jati diri. Dalam masa remaja tersebut, sering dilukiskan sebagai masa badai dan topan karena ketidaksesuaian antara perkembangan psikis dan sosial. Upaya-upaya untuk menemukan jati diri tersebut, tidak semua dapat berjalan lancar sesuai harapan masyarakat. Beberapa remaja melakukan perilaku merokok sebagai perilaku kompensatoris. Pada dasarnya perilaku merokok adalah perilaku yang dipelajari. Hal ini berarti ada pihak-pihak yang berpengaruh besar dalam proses sosialisasi (Rachmat, 2012). Perilaku merokok pada siswa hendaknya diarahkan, sehingga dapat berhenti dan tidak berlanjut sampai dewasa yang merugikan bagi kesehatan secara khusus maupun individu secara umum.

\section{Pengetahuan dan perilaku merokok}

Pengetahuan merupakan domain terpenting bagi terbentuknya tindakan seseorang. Perilaku yang disadari oleh pengetahuan akan lebih langgeng daripada perilaku yang tidak disadari oleh pengetahuan (Kholid, 2014). Hasil penelitian menunjukkan bahwa lebih banyak responden yang memiliki pengetahuan baik (76,95\%), memiliki pengetahuan kurang yang merokok sebanyak $66,7 \%$, dan pengetahuan baik yang merokok sebanyak 68 orang (52,3\%). Hasil analisis bivariat menunjukkan tidak ada hubungan antara pengetahuan dengan perilaku merokok $(\mathrm{p}=0,162)$. Hasil wawancara bahwa seluruh informan memiliki pengetahuan yang baik tentang rokok.

Hasil penelitian ini didukung dengan hasil penelitian Rachmat, Thaha dan Syafar (2013) bahwa pengetahuan responden tentang merokok berada pada kategori tinggi (83,4\%). Responden berpengetahuan tinggi yang merokok adalah $27,0 \%$, lebih besar dari responden berpengetahuan rendah 
yang merokok $(16,7 \%)$. Tidak ada hubungan antara tingkat pengetahuan dengan perilaku merokok remaja (nilai $\mathrm{p}=0,056$ ) (Rachmat, Thaha, \& Muhammad Syafar, 2013).

Pengetahuan merupakan modal dasar bagi seseorang untuk berperilaku. Pengetahuan yaang cukup akan memotivasi individu untuk berperilaku baik. Orang yang dipenuhi banyak pengetahuan akan mempersepsikan informasi tersebut sesuai dengan predisposisi psikologisnya. Pengetahuan yang tinggi tentang rokok pada remaja cenderung memperkecil kemungkinan remaja tersebut berperilaku merokok. Hal ini disebabkan remaja tersebut telah mengetahui bahaya atau dampak negatif yang ditimbulkan oleh rokok (Agus \& Nopianto, 2017).

Pengetahuan, pengetahuan tentang rokok merupakan salah satu aspek yang berperan pada pembentukan perilaku merokok. Tetapi pada kenyataannya pengetahuan tentang rokok tidak signifikan berhubungan dengan perilaku merokok pada remaja, kondisi ini disebabkan pada masa usia remaja keinginan tahu tentang rokok tinggi, jadi dengan adanya pengetahuan tentang rokok tidak akan berpengaruh terhadap perilaku remaja dalam merokok. Remaja mengetahui tentang bahaya merokok, tetapi pada kenyataannya remaja tetap berperilakua merokok, remaja lebih pada rasa ingin tahunya tentang rokok. Pengetahuan dibagi menjadi enam tingkatan yaitu tahu, memahami, aplikasi, analisis, sintesis, dan evaluasi.

Tidak ada hubungan perilaku merokok dengan pengetahuan dapat terjadi karena adanya pengaruh teman sebaya. Jika, responden berpengetahuan baik tetapi masih dalam tahap "tahu" dan belum sampai ke tahap "evaluasi" artinya responden belum memiliki kemampuan untuk mengambil keputusan tentang apa yang baik dan buruk bagi dirinya.

\section{Pola asuh dan perilaku merokok}

Pola asuh merupakan suatu keseluruhan interaksi antara orang tua dengan anak, dimana orang tua bermaksud menstimulasi anaknya dengan mengubah tingkah laku, pengetahuan serta nilai-nilai yang dianggap paling tepat oleh orang tua, agar anak dapat mandiri, tumbuh dan berkembang secara sehat dan optimal. Pola asuh demokratis adalah pola asuh yang memprioritaskan kepentingan anak, tetapi tidak ragu-ragu mengendalikan mereka. Orang tua tipe ini juga memberikan kebebasan kepada anak untuk memilih dan melakukan suatu tindakan, dan pendekatan kepada anak bersifat hangat. Pola asuh demokratis ditandai dengan ciri-ciri bahwa anak diberi kesempatan untuk mandiri dan mengembangkan kontrol internalnya, anak diakui keberadaannya oleh orangtua dan anak dilibatkan dalam pengambilan keputusaan (Desmita, 2017).

Hasil penelitian menunjukkan lebih banyak responden yang memiliki pola asuh demokratis yaitu 149 orang $(88,2 \%)$ dan sebanyak 20 orang $(11,8 \%)$ memiliki pola asuh otoriter. Dari 169 responden yang memiliki pola asuh demokratis yang merokok sebanyak 84 orang $(56,4 \%)$, dan pola asuh otoriter yang merokok sebanyak 10 orang $(50 \%)$. Hasil analisis menunjukkan tidak ada hubungan antara pengetahuan dengan perilaku merokok $(\mathrm{p}=0,765)$. Hasil wawancara bahwa seluruh informan memiliki pola asuh demokratis.

Pola asuh orangtua merupakan salah satu aspek terpenting yang secara signifikan turut membentuk perilaku dan karakter seorang. Hal ini didasari bahwa pendidikan dalam keluarga adalah pendidikan yang utama dan pertama bagi anak, yang tidak bisa digantikan oleh lembaga pendidikan manapun. Pola asuh yang kurang baik dalam keluarga akan menimbulkan perilaku yang menyimpang pada anak usia remaja, salah satu yang sering dilakukan oleh sebagian remaja adalah dengan merokok, para anak remaja menganggap dengan menggunakan zat berbahaya tersebut, remaja cenderung merasa lebih percaya diri (Meilany, Hendro, \& Yudi, 2015).

Pada dasarnya kebiasaan merokok anak memang tidak terlepas dari pendidikan dalam keluarga yaitu pola asuh orang tua tetapi hal tersebut juga tidak sepenuhnya diakibatkan oleh pola asuh orang tua, 
melainkan diakibatkan oleh pengaruh dari luar seperti faktor lingkungan dimana anak tersebut bergaul, teman sebaya, dan media sosial seperti iklan televisi

Pola asuh orang tua merupakan pendidikan dasar yang akan membentuk karakter seorang anak, seorang anak remaja menginginkan pola asuh yang demokratis yang tidak memberikan tekanan pada perkembangannya. Tidak adanya hubungan pola asuh dengan perilaku merokok, dapat terjadi karena faktor lain yang lebih berpengaruh seperti teman sebaya, guru, bahkan keluarga merokok. Siswa tidak memperoleh keteladaan di lingkungannya yang tidak merokok.

\section{Teman sebaya dan perilaku merokok}

Remaja lebih banyak berada di luar bersama dengan teman sebaya sebagai kelompok, maka dapatlah dimengerti bahwa pengaruh teman-teman sebaya pada sikap, pembicaraan, minat, penampilan dan perilaku lebih besar daripada pengaruh keluarga (Hurlock, 1980). Hasil penelitian menunjukkan bahwa lebih banyak responden yang ada pengaruh teman sebaya yaitu 90 orang $(53,3 \%)$ dan sebanyak 79 orang $(46,7 \%)$ yang tidak ada pengaruh teman sebaya. Dari 169 responden yang ada pengaruh teman sebaya dan merokok sebanyak 83 orang $(92,2 \%)$ dan tidak ada pengaruh teman sebaya dan merokok sebanyak 11 orang $(13,9 \%)$. Hasil analisis menunjukkan ada hubungan antara pengaruh teman sebaya dengan perilaku merokok $(\mathrm{p}=0,000)$. Hasil wawancara bahwa seluruh informan memiliki teman yang merokok baik teman main di rumah maupun di sekolah. Hal ini didukung dengan hasil penelitian Lindawati (2011), sebagian besar responden $(66,0 \%)$ yang merokok karena mendapat pengaruh dari teman. Hasil analisis menunjukkan adanya hubungan yang bermakna antara pengaruh teman dengan perilaku merokok $(\mathrm{p}=0,000)$. Pengaruh teman sebaya mempunyai risiko 73 kali meningkatkan perilaku merokok (OR=73,299 CI 95\%: 0,304-1,970).

Hasil penelitian ini sesuai dengan penelitian sebelumnya. Hasil penelitian Widiansyah (2014) bahwa aspek lingkungan yang mempengaruhi perilaku merokok remaja salah satunya adalah teman sekolah maupun teman sepermainan karena keakraban serta seringnya mereka berkumpul dan berkomunikasi maka teman yang merokok sangat mudah mempengaruhi teman yang tidak merokok menjadi merokok. Hal tersebut karena remaja biasanya ingin meniru maupun mencoba apa yang mereka belum pernah rasakan. Salah satunya yaitu mencoba merokok seperti yang dilakukan teman mereka yang merokok. Teman dengan mudahnya mempengaruhi teman yang lain karena dalam diri remaja terjalin rasa kebersamaan apalagi teman tersebut sering berkumpul dan sering jalan bersama (Widiansyah, 2014).

Semakin banyak remaja merokok, maka semakin besar kemungkinan teman-temannya menjadi perokok juga. Hal ini dapat dilihat dari dua kemungkinan yang terjadi, remaja tersebut terpengaruh oleh teman-temannya atau teman-temannya yang dipengaruhi oleh remaja tersebut sehingga akhirnya semua menjadi perokok.

\section{Iklan rokok dan perilaku merokok}

Iklan rokok sebagai media promosi rokok sangat potensial membentuk sikap dan perilaku merokok remaja (Rachmat, Thaha, \& Syafar, 2013). Pengetahuan tentang rokok banyak didapatkan melalui iklan rokok, baik jenis rokok terbaru maupun bahaya dari rokok itu sendiri (Rachmat et al., 2013). Dalam menyampaikan informasi sebagai tugas pokoknya, media massa membawa pula pesanpesan yang berisi sugesti yang dapat mengarahkan opini seseorang. Pesan-pesan sugesti yang dibawa oleh informasi tersebut, apabila cukup kuat, akan memberi dasar afektif dalam menilai sesuatu hal sehingga terbentuklah arah sikap dan perilaku tertentu (Azwar, 2011).

Hasil penelitian menunjukkan bahwa lebih banyak responden yang terpengaruh keterpaparan iklan rokok 78,1\% dan sebanyak 21,9\% yang tidak terpengaruh keterpaparan iklan rokok. Dari 169 responden yang terpengaruh keterpaparan iklan rokok yang merokok sebanyak $62,1 \%$, sedangkan 
responden yang tidak terpengaruh keterpaparan iklan rokok yang merokok sebanyak $32,4 \%$. Hasil analisis menunjukkan ada hubungan antara keterpaparan iklan rokok dengan perilaku merokok $(\mathrm{p}=0,002)$. Keterpaparan iklan rokok mempunyai risiko 3,4 kali meningkatkan siswa berperilaku merokok (OR=3,417 CI 95\%: 1,577-7,401). Hasil wawancara bahwa seluruh informan pernah melihat iklan rokok terutama di televisi.

Melihat iklan di media massa dan elektronik yang menampilkan bahwa perokok adalah lambang kejantanan atau glamor membuat remaja seringkali terpicu untuk mengikuti perilaku seperti iklan tersebut. Remaja rawan untuk terpengaruh iklan rokok karena iklan rokok dapat menjadi instrumen dalam masa inisiasi remaja untuk merokok. Masa inisiasi merupakan tahapan yang kritis pada seorang individu karena merupakan tahap coba-coba dimana ia beranggapan bahwa dengan merokok ia akan terlihat keren sehingga ia akan memulai dengan mencoba beberapa batang rokok.

Pendidikan primer dimulai dari lingkungan keluarga. Orang tua secara langsung mempengaruhi pembentukan kepribadian anak-anaknya yang dalam hal ini adalah remaja. Apabila orang tua yang sekaligus sebagai role model keliru dalam memberikan pendidikan kepada anaknya, maka hal tersebut akan dibawa oleh remaja sebagai perilaku yang menunjukkan kepribadian mereka.

\section{Lingkungan keluarga dan perilaku merokok}

Orangtua merokok merupakan sumber penting kerentanan terhadap inisiasi merokok di kalangan remaja dan orangtua yang berhenti merokok menipiskan kerentanan tersebut. Risiko permulaan merokok anak-anak dengan orangtua yang merokok meningkat sesuai dengan durasi mereka terpapar dengan orangtua yang merokok. Hal ini mendukung hubungan dosis-respon antara orangtua yang merokok dengan keturunan mereka merokok (Rachmat, Thaha \& Syafar, 2017).

Hasil penelitian menunjukkan bahwa lebih banyak responden yang tidak terpengaruh lingkungan keluarga (87\%) dan sebanyak 13\% yang ada pengaruh lingkungan keluarga. Dari 169 responden yang ada pengaruh lingkungan keluarga dan merokok sebanyak 20 orang $(90,9 \%)$ sedangkan responden yang tidak ada pengaruh lingkungan keluarga dan merokok sebanyak 74 orang $(50,3 \%)$. Hasil analisis menunjukkan ada hubungan antara lingkungan keluarga dengan perilaku merokok $(\mathrm{p}=0,001)$. Faktor lingkungan keluarga mempunyai risiko 9,8 kali meningkatkan siswa berperilaku merokok ( $\mathrm{OR}=9,865$ CI 95\%: 2,225-43,731). Hasil wawancara bahwa sebagian besar informan mengatakan dalam keluarganya ada yang merokok.

Perilaku merokok orang tua sangat mempengaruhi perilaku merokok anaknya. Perilaku anak terbentuk karena mencontoh dan contoh yang paling cepat ditiru adalah contoh yang paling bersumber dari orang yang paling bermakna dalam kehidupan seorang anak yaitu keluarga. Melalui keluargalah anak belajar bertingkah laku sosial dalam hal ini adalah orang tuanya. Karena betapa mudahnya anak meniru perilaku orang tuanya.

Perilaku orang, lebih-lebih perilaku anak kecil lebih banyak dipengaruhi oleh orang-orang yang dianggap penting. Apabila seseorang itu percaya, maka apa yang ia katakan atau perbuat cenderung untuk dicontoh. Untuk anak-anak sekolah misalnya, maka gurulah yang menjadi panutan perilaku mereka (Notoatmodjo, 2012).

Perilaku merokok Guru di sekolah tidak menunjukkan perilaku yang seharusnya dilakukan oleh seorang pendidik. Para pendidik di sekolah diharapkan menyelenggarakan pendidikan dan pembelajaran yang mampu memfasilitasi peserta didik berperilaku terpelajar. Salah satu aspeknya yaitu dengan menciptakan lingkungan yang bersih termasuk menciptakan lingkungan yang bebas asap rokok merupakan faktor yang penting bagi pertumbuhan dan perkembangan peserta didik.

Hasil penelitian menunjukkan bahwa lebih banyak responden yang ada pengaruh guru 59,2\% dan sebanyak 40,8\% yang tidak ada pengaruh guru. Dari 169 responden yang ada pengaruh guru dan merokok sebanyak $70 \%$, sedangkan responden yang tidak ada pengaruh guru dan merokok sebanyak 
43,8\%. Hasil analisis menunjukkan ada hubungan antara pengaruh guru dengan perilaku merokok $(\mathrm{p}=0,000)$. Faktor pengaruh guru secara statistic mempunyai risiko 4,3 kali meningkatkan siswa berperilaku merokok (OR=4,375 CI 95\%: 2,274-8,418). Hasil wawancara bahwa seluruh informan mengatakan ada guru yang merokok dan menjadi ingin merokok ketika melihaat guru yang merokok.

Hasil penelitian ini didukung oleh penelitian Lindawati (2011) yang memperlihatkan ada hubungan yang bermakna antara pengaruh guru dengan perilaku merokok $(\mathrm{p}=0.000$; OR=3.922 CI 95\%: 1.783-8.625) (Lindawati, Miradwiyana, \& Sumiati, 2012). Selain orang tua, guru merupakan orang tua kedua bagi remaja ketika di sekolah. Peran seorang guru juga tidak jauh berbeda dengan orang tua di rumah yakni sebagai role model yang baik bagi remaja. Ketidak konsistenan antara larangan merokok di tempat pendidikan dengan perilaku merokok pada guru membuat remaja berdalih ketika didapati merokok di lingkungan sekolah.

\section{Uang jajan dan perilaku merokok}

Rokok merupakan barang yang sangat mudah didapatkan di masyarakat. Harga yang sangat terjangkau dan dapat diperoleh di berbagai tempat akan memberikan dampak buruk terhadap remaja. Uang jajan berpotensi sebagai faktor munculnya perilaku merokok siswa yang disebabkan karena tidak adanya pemantauan dari orangtua terhadap pengeluaran uang jajan. Siswa yang memiliki uang jajan tinggi maupun rendah dapat membeli rokok dengan harga rokok per batang (harga satu batang rokok sama dengan Rp.1500) dari menyisihkan sebagian kecil uang jajan mereka.

Hasil penelitian menunjukkan bahwa lebih banyak responden yang memiliki uang jajan rendah yaitu $64,5 \%$ dan sebanyak 35,5\% yang memiliki uang jajan tinggi. Dari 169 responden yang memiliki uang jajan tinggi dan merokok sebanyak 70\%, sedangkan responden yang memiliki uang jajan rendah dan merokok sebanyak $47,7 \%$. Hasil analisis menunjukkan ada hubungan antara uang jajan dengan perilaku merokok $(\mathrm{p}=0,009)$, namun nilai $\mathrm{OR}=0,391$ artinya uang jajan rendah menjadi proteksi untuk berperilaku merokok.

Faktor uang jajan rendah menjadi proteksi dapat terjadi, karena kemampuan siswa membeli rokok lebih rendah dibanding siswa dengan uang jajan lebih besar. Pemberian uang saku seharusnya diberikan dengan dasar kebijakan dan tidak berlebihan. Uang saku yang diberikan dengan tidak bijaksana akan dapat menimbulkan masalah, yaitu remaja menjadi boros, remaja tidak menghargai uang dan remaja malas belajar, sehingga remaja cenderung tergoda dan merasa kecanduan dengan rokok karena harga rokok yang tidak mahal dan boleh membeli perbatang.

\section{Simpulan dan saran}

Perilaku merokok pada siswa berjumlah $55,6 \%$ orang. Faktor terpengaruh teman sebaya, keterpaparan iklan rokok, lingkungan keluarga, terpengaruh guru merokok dan uang jajan meningkatkan perilaku merokok pada siswa. Perlu upaya menurunkan perilaku merokok pada usia muda (siswa) dengan memberikan keteladaan baik oleh lingkungan internal, yaitu keluarga maupun lingkungan eksternal, seperti guru, teman sebaya maupun pemerintah terkait pembatasan lingkungan merokok.

\section{Referensi}

Agus, A., \& Nopianto. (2017). Determinan Perilaku Merokok Pada Remaja. Journal Endurance, 2(1), 25-30.

Azwar, S. (2011). Sikap Manusia Teori dan Pengukurannya (2nd ed.). Yogyakarta: Pustaka Pelajar.

Badan Penelitian dan Pengembangan Kesehatan Departemen Kesehatan RI. (2009). Laporan Hasil Riset Kesehatan Dasar (Riskesdas) Provinsi Lampung Tahun 2007. Jakarta.

Desmita. (2017). Psikologi Perkembangan. (Muchlis, Ed.). Jakarta: PT Remaja Rosdakarya.

Farida, F. (2015). Analisis Faktor-Faktor Penyebab Perilaku Rokok Remaja di SMK "X" Surakarta. Jurnal Kesehatan Masyarakat, 3(3), 887-897. 
Hurlock, E. B. (1980). Psikologi Perkembangan Suatu Pendekatan Sepanjang Rentang Kehidupan. (R. M. Sijabat, Ed.) (5th ed.). Jakarta: Erlangga.

Kemenkes RI. (2016). Perilaku Merokok Mayarakat Indonesia Berdasarkan Riskesdas 2007 dan 2013. Jakarta.

Kholid, A. (2014). Promosi Kesehatan dengan Pendekatan Teori Perilaku, Media, dan Aplikasinya. Jakarta: Rajawali perss.

Lindawati, Miradwiyana, B., \& Sumiati. (2012). Faktor-Faktor yang Mempengaruhi Perilaku Merokok SiswaSiswi di Daerah Jakarta selatan tahun 2011. Jurnal Health Quality, 2(4), 189- 200.

Meilany, D. J., Hendro, B., \& Ismanto A Yudi. (2015). Hubungan antara Pola Asuh Orang Tua dengan Kebiasan Merokok Anak Usia Remaja 12-17 tahun di Desa Kilometer 3 Kecamatan Amurang. Ejournal Keperawatan, 3(1), 8 [Screen].

Notoatmodjo, S. (2012). Promosi Kesehatan dan Perilaku Kesehatan. Jakarta: Rineka Cipta.

Novita, N., \& Yunetra Franciska. (2011). Promosi Kesehatan dalam Pelayanan Kebidanan. (A. Suslia, Ed.). Jakarta: Salemba Medika.

Rachmat, M. (2012). Buku Ajar Biostatistika Aplikasi pada Penelitian Kesehatan. Jakarta: EGC.

Rachmat, M., Thaha, R. M., \& Muhammad Syafar. (2013). Perilaku Merokok Remaja Sekolah Menengah Pertama. Jurnal Kesehatan Masyarakat Nasional, 7(11), 502-508.

Sinaga, D. (2017). Rokok: Jerat Kematian dan Kemiskinan. Jakarta.

Syafrudin, \& Yudhia Fratidhina. (2009). Promosi Kesehatan untuk Mahasiswa Kebidanan. Jakarta: Trans Info Media.

Trihono. (2013). Riset Kesehatan Daar 2013. Jakarta: Kementerian Kesehatan Republik Indonesia.

Widiansyah, M. (2014). Faktor-Faktor Penyebab Perilaku Remaja Perokok di Desa Sidorejo Kabupaten Penajam Paser Utara. Ejournal Sosiologi, 2(4), 12-23. 